\title{
Assessment of Seismogeodynamic Activity of Mining Areas on the Basis of 3D Geoinformation Modeling
}

\author{
V. A. Petrov, V. A. Minaev, S. A. Ustinov, I. O. Nafigin, and A. B. Lexin \\ Institute of Geology of Ore Deposits, Petrography, Mineralogy and Geochemistry Russian Academy of Sciences (IGEM RAS), \\ Staromonetny Pereulok, 35, Moscow, Russia
}

Received 26 July 2021; accepted 18 November 2021; published 9 December 2021.

\begin{abstract}
The article deals with the creation of an information and analytical platform for assessing external causes of technogenic (man-made) accidents and for improving methods of their predication and prevention on the territories of long-term geological, mining, and engineering activities on the Southeastern (SE) Transbaikal region example - one of the key areas for mining and extraction of the strategic raw minerals in Russia. 3D modeling of active geological structures and hazardous seismogeodynamic processes on GIS-based technologies is a key instrument for forecasting dangerous natural and technogenic events and risk reduction of their occurrence. A matter of minimizing consequences of natural and technogenic disasters for such facilities of increased technological and environmental hazards as minefields, radiochemical facilities, sites for spent nuclear material disposal, dams, gas and oil pipelines, etc. has become essential. It is necessary to assess modern geodynamic territory's activity on a unified geoinformation platform applying the newest integrated geological-geophysical researches' methods for these objects, to select seismically active fault-fracture zones, to determine the rate and direction of surface displacement, to establish patterns of subsoil stressed-strained state natural component influence on behavior of local technogenic processes. Taking into account the specificities of geotectonic structure of mining territories, the structure of monitoring seismogeodynamic processes network on multifunctional geodynamic test sites should be developed. Observations made on test sites form the information basis for forecasting of lithosphere condition, taking decisions on rational subsurface management and providing ecological safety of the territory.
\end{abstract}

Keywords: active geological structures, hazardous seismic and tectonic processes, stressed-strained state of rocks, database, geoinformation system, three-dimensional modeling, deposits of strategic mineral resources, monitoring of natural and technogenic phenomena, southeastern Transbaikal

Citation: Petrov, V. A., V. A. Minaev, S. A. Ustinov, I. O. Nafigin, and A. B. Lexin, (2021), Assessment of Seismogeodynamic Activity of Mining Areas on the Basis of 3D Geoinformation Modeling, Russ. J. Earth. SCI., Vol. 21, ES6003, 10.2205/2021ES000781.

In memory of A. N. Plate

\section{INTRODUCTION}

The researches referred to in this article are aimed at solving of a major scientific problem - revealing the development patterns of modern seismotectonic processes, that suddenly manifest themselves in a variety of geological structures, creating the conditions for man-made accidents on territories where facilities of increased environmental and radiation risk (minefields, radiochemical plants, spent nuclear material containment, sites, dams, gas- and oil pipelines, etc.) are located. This scientific problem solution is implemented on the basis of information and analytical complex of three-dimensional modeling of active geological structures and forecast of their stressed-strained state (SS state), developed through the use of GIS - based technologies on the example of SE Transbaikal.

\footnotetext{
${ }^{*}$ Corresponding author: vlad243@igem.ru
}

\section{RELEVANCE OF SCIENTIFIC PROBLEM}

The accelerated development of the country's economic potential, including in mining, nuclear power and construction, is taking place against the backdrop of an increase in natural anomalies [Gliko, 2011]. They can be almost instantaneous, as in an earthquake, or can be triggered by very long term changes of regional geodynamic conditions [Sobolev, 2010]. Anthropogenic interference to the natural environment has previously caused and may cause in the future man-made accidents that generated into environmental disasters [Adushkin and Turuntaev, 2005; Catalogue, 1989; Kurlenia et al., 2005]. These circumstances bring additional requirements to the level of scientific knowledge in this field.

The most particularly relevant issue is the prevention or minimization of the natural and manmade disasters consequences for such facilities of 
increased technological and environmental danger, as mining fields, radiochemical plants, isolation sites for spent nuclear materials, dams, gas and oil pipelines and etc.

For these facilities it is necessary to assess the current geodynamic territory's activity on a single geoinformation platform using the latest methods of integrated geological and geophysical surveys, to highlight and evaluate seismically active faultfracture zones, to establish the influence of natural component patterns of subsoil SS state on local surface and underground technogenic processes especially in mining territories.

Taking into account the specific nature of geological tectonic structure of different territories, a network structure for seismic geodynamic processes monitoring on many functional test sites should be developed [Bortnikov et al., 2012; Petrov et al., 2014, 2017b]. The observations carried out at the test sites form the information basis for predicting the lithosphere state, taking decisions on the subsoil rational management and ensuring the ecological security of the territories.

For example, most of large and unique deposits of strategic and much-needed in industry variety of minerals (uranium, gold, rare metals, etc.) in the geological past formed in activated mobile zones on the borders of stable lithospheric blocks [Bortnikov, 2012; Bortnikov and Petrov, 2020; Laverov and Rundkvist, 2020]. These global suture zones are currently characterized by intense tectonic disturbance and seismic activities. Therefore, mining companies located here, are of high technological and environmental hazards.

Technogenic hazards is defined by the fact that in circumstances of increased worked-out area and relocation of mining front to deep horizons of geological cross-section manifestation of underground pressure intensifies. Against the background changes of rock's massifs SS state changes this often leads to rock-tectonic concussions (rock burst and technogenic earthquake) of high destructive power. As a result, mining enterprises have to wind down or completely stop the work. In circumstances when an enterprise is town-forming, this multiplies negative effects - socio-economic risks and consequences.

Environmental risk is associated with mining and processing of ore mass when huge amount of chemical elements placed in open piles and tailing dams are generated. Damage of these objects' integrity as a result of natural and technogenic deformations accompanied by all ecosystems degradation, including removing pollutants (radionuclides, heavy metals) and contamination of groundwater aquifers used for public water supply.

Russia has all basic conditions for improving technologies for monitoring, assessment and fore- casting hazardous seismogeodynamic events. Over the previous decades organization monitoring networks after the deformation of lithospheric blocks has become one of the most important tools for solving fundamental and applied problems that are of particular importance to the national economy and the country's security. These data were reflected in a set of maps for general seismic area zoning of the Russian Federation Territory (OSR-97) [OSR-97, 1999]. They have been supplemented by the establishment of OSR-2012/2014/2016 [Ulomov and Bogdanov, 2017]. It should be noted that the set of maps OSR-2016 has been completed with a map D, intended for nuclear industry facilities in accordance with the requirements of the International Atomic Energy Agency [Bugaev et al., 2005].

A demonstrative example of how to solve a complex problem of management is a system of permanent and temporary observation stations of "Baikal geodynamic polygon" that covers area north of Baikal Lake, Eastern Sayans, Tuva, Central and Western Mongolia and was set up at the end of the 20th century [Luhnev et al., 2010; Sankov et al., 2005]. Research results on the territory contributed significantly to taking a decision to change the oil pipeline route "Eastern Siberia - Pacific Ocean" away from Baikal Rift Zone within which modern seismic activity is intensively presented.

The SE Transbaikal region has historically been an essential supplier of strategic minerals and metals for the needs of the country's economy, including gold, uranium, copper, rare metals, etc. With the adoption of Federal Law from 29 December 2014 No. 473-FL"Over territories of Leading Socioeconomic development in the Russian Federation", "Strategies for socio-economic development in the Far East and Baikal region for the period till 2025" (Resolution of the Government of the Russian Federation No. 2094-p of 28 December 2009), "Strategies for the socio-economic development of the Baikal region up to 2030" (Decree of the Transbaikal region Government from 28 January 2019 No. 14 with changes) and other strategic planning documents, the territory is receiving close attention as a key source of mineral resource base (MRB) of strategic raw materials for the development of high technologies and import substitution in the Russian Federation.

But future prospects for the development (reproduction) of MRB associated here with work on the deep horizons of long-term exploitable ore deposits in increasingly complex geological conditions. The introduction of new large-scale mines is largely constrained by the fact that thus issues of external natural causes and sources determining local mining and geological conditions and the level of man-made accidents are not studied. In addition, a number of areas of the SE Transbaikal region are considered po- 
tentially to be very favorable for building subsurface radioactive waste storage facilities and long-term nuclear material isolation facilities in deep-seated formations [Ahern and Laverov, 2009]. Monitoring and rehabilitation activities are also required on long-term exploitable radioactively hazardous facilities [Rostekhnadzor, 2005] to which, first of all, "Priargunsky Industrial Mining and Chemical Union named after E. P. Slavsky" ("PIMCU") in the Krasnokamensk town- the largest uranium ore mining and processing enterprise in Russia - belongs.

The need to develop and implement methods and tools for forecasting emergencies, and risk reduction for SE Transbaikal is largely due to the fact that with a relatively good geological-geophysical and metallogenic knowledge, this territory is not provided with a monitoring systems on development of modern seismogeodynamic processes. Therefore, numerous mining enterprises and radiochemical facilities are areas of high ecological risk. Lack of predictive information in determining the development of seismic geodynamics processes in areas of intensive industrial activity creates serious obstacles for activities development and implementation to prevent or reduce the consequences of natural disasters and technogenic accidents.

Thus, it is necessary to set up an information and analytical complex of a three-dimensional (3D) modeling of active geological structures and forecasting of dangerous seismogeodynamic processes development using GIS technologies for the SE Transbaikal territories, taking into account the specificity of its geological and tectonic structure and heterogeneity of geophysical fields. The project World Stress Map (WSM) started in 1986, is an example of such complexes that bringing together cartographic and geophysical data on deep composition of seismic generating structures and assessment of their seismic hazard, and in 2017 its 4th stage began. This global GIS includes more than 22000 points of permanent and temporary observations after lithospheric deformations worldwide [Heidbach et al., 2016]. But the project doesn't cover the SE Transbaikal territory and the data received within its framework can't be used for analysis and assessment of modern seismogeodynamic territory's activity.

Information and analytical complex of 3D modeling of active geological structures in the SE Transbaikal region with a GIS platform, is capable to integrate:

1. Territorial centralized and thematically distributed geological and geophysical database;

2. 2- and $3 \mathrm{D}$ models of lithospheric blocks with tectonic element distribution and seismogenic structure framework;
3. Numerical 2- and 3D models of modern SS state of rock massifs and active fault- fracture zones.

Such information and analytical complex is aimed at localization development zones of dangerous seismogeodynamic processes and their accurate positioning on location, including using space geodesy data in terms of space and time associated fields of strain generation to specific geological structures for the establishment of monitoring sites.

It will provide a scientific basis for a quantative estimation and prognostication of the lithosphere state, the purpose of which is to minimize any risk and reduce consequences of catastrophic events of natural and technogenic origin, and also for making decisions on rational natural resources management and providing ecological safety for economic objects of the SE Transbaikal territory.

Along with this, real possibility of modern information management of fundamental, exploratory and applied researches is created in the area of the Earth and rational use of natural resources. Besides supplemental (metainformation) and documentary data complete (primary) information about objects and processes accumulate in engineered informative complex and can be given to users:

- Factual database;

- Digital maps;

- Electronic worksheet;

- Of special purpose GIS apps;

- Aero- and satellite images;

- Scientific and measurement based information, etc.

Researchers, employees from management and manufacture sectors using GIS system can receive operative multilevel access to informative resources and technologies in modern centers of scientific information, global information and computer networks. For this purpose the user is provided by a corresponding interface to means of certain tasks' solving and a typical description of implementation user's assignments.

\section{State of The PROBlem AND RESEARChes' METHODOLOGY}

Presently basic study directions of external natural reasons of technogenic accident occurrences and improving methods of their prediction and prevention in the world science and practice include:

1. Development of multifunctional and problemoriented GIS and advanced intellectual expert systems;

2. Development methods for predicting natural and technogenic emergencies on a quantative basis. 
A dynamic development takes place in this regard:

- Data collection and processing technologies for integrated information resources on the Internet (Web), network analysis technologies of Geographic Information Systems (GIS) and distributed computing network technologies (GRID);

- Technologies for spatial and temporal modeling of various natural and technogenic processes and phenomena;

- Technologies to provide service support and rapid multi-level access to information resources.

Geoinformation system establishment that gives a possibility to reflect spatial data in a threedimensional view (3D GIS), is an innovative direction in informatics. Basic meaning of 3D GIS is to form visual pattern models, foremost, largescale objects. 3D information about objects is used for control and management by a man (operator), which means that the model is a data source. On the basis of displayed information a conceptual model of processes and phenomena is generated by the operator. 3D information model provides the most complete conceptual model and its adequacy for displayed objects that in most cases are volumetric. The necessity of 3D informative model arises when studying land relief, 3D structure of geological and archaeological objects using GIS, remote control of robotics, automatic research apparatus, etc. In a number of cases, for example, when one represented object is eclipsed by another, the need for developing a multi-dimensional 3D information model is required.

Methods, technical means and a variety of 3D visualization products of GIS-based geological and tectonic structure of the territories are now becoming increasingly important for studying deep constitution of seismogenic structures, assessment of their SS state, seismic hazard - data needed to take decisions whether to undertake mining, engineering or environmental protection measures in a particular territory.

In this context, the best examples of implementation are:

1. Previously mentioned project World Stress Map (WSM) - global information system on the stressed-strained state of the Earth's crust [WSM, 2021]. The project started in 1986 as a part of the International Lithosphere Program (ILP), from 1995 to 2008; it was Heidelberg Academy of Sciences and Humanities project; from 2009 it is realized in Helmholtz Center Potsdam - GFZ German Research Center for Geosciences, Germany. WSM project, combin- ing more than 22000 permanent and temporary observation stations after lithosphere deformations, is constantly replenished. The materials reflected in this global GIS, are used for tackling a wide range of scientific and practical challenges;

2. A joint program CHAMP (Satellites like Challenging Mini-satellite Payload), GRACE (Gravity Recovery and Climate Experiment) and COGE (Gravity Field and steady state Ocean Circulation Explorer) studying the Earth's gravitational and magnetic fields from space. This program was launched in 2007. A special structure was organized to achieve program' goals German Geoscience Research and Implementation Program "Geotechnologien" [Geotechnologien, 2021], co-financed by the German Federal Ministry for Education and Research (BMBF) and the German Science Foundation (DFG) with additional funding from private investors;

3. Draft Gravimetric Measurements of International Gravimetric Bureau (BGI, Toulouse, France). This project brings together all of the world's data on gravimetry that are placed on an information resource BGI [2021]. Project materials are also used to meet various scientific and practical challenges;

4. The newest methods of formalization, interpolation, geometric and spatial data processing of the Earth's remote sensing received with the help of permanent reflectors (PS), small baselines (SBAS), channels rotation, main component analysis, classification, lineament analysis and etc. Received types of data: panchromatic, multispectral, radar space photographs; digital terrain (or elevation) models; text, digital and raster data. The main sources of information are The Copernicus Open Access Hub, The USGS Earth Explorer, The Earth Observing System Data and Information System, Roscosmos geoportal, reports and articles.

There are many other examples, but we should note that neither Russian nor foreign developers realized the commitments on studying and forecasting development patterns of modern geodynamic processes and seismotectonic events for objects of enhanced technogenic and environmental hazards through the integration of fundamental results and applied researches combined into geoinformation and analytical, geostructure-tectonic and predicting geodeformation blocks. In such a statement the question is formulated for the first time.

The world's main scientific competitors in the field of improved forecasting and prevention of man-made accidents should also be mentioned. Market trends in knowledge-based products are such that many companies are currently developing 
3D GIS of different types, including: Alioscopy, Apple, 3D Icon, Dimension Technologies Inc., Fraunhofer HHI, Holografika, i-Art, NewSight, StereoPixel, DDD, SeeFront, SeeReal Technologies, Spatial View Inc., Tridelity, VisuMotion, Zero Creative (xyZ), etc.

A number of specialized institutions and organizations abroad are systematically analyzing the situation in the field of space-time modeling of seismogeodynamic processes, and long-term forecasting of the geological environment state, assessment of the risk occurrence and natural and man-made disasters' consequences.

Optimal strategies and information flows processing technologies are being developed. The comparison of different technologies of spatial $(2 \mathrm{D}, 3 \mathrm{D})$ and temporal (4D) modeling of hazardous seismogeodynamic processes is being conducted. On specialized scientific and methodological materials, GISsystems are being developed for territories zoning on the basis of seismic hazards and 3D modeling of seismic and active geodynamic processes. Theoretical (mathematical) justification of the 3D capacity information increase (in coordinate space) of visual models and 3D objects' visualization technologies, such as IMAX 3D, are being developed.

One of the recognized leaders in $2 \mathrm{D}, 3 \mathrm{D}$ and $4 \mathrm{D}$ modeling of complex geological structures is the Paradigm company that has implemented a new geological modeling technology (UVT Transform). The technology allows the transition to pillarless implementation of grid models, which allows conducting synthesis of geological and geophysical information [Mallet, 2004; Mallet and Tertois, 2021].

One of the leaders in conceptual modeling for predictive purposes (semi-quantitative description of geodynamic processes and phenomena leading to the different mineral deposits formation) on GISbasis is the University of Western Australia (Center for Exploration Purposes) in the city of Crowley [Kreuzer et al., 2010].

Here with the support of mining companies, a center to analyze geological and geophysical data, combined into GIS projects for territories assessment, including highly seismic, aimed at reducing the technical and financial risks associated with their exploration, has been set up.

More recently, the search for ways to reduce the risk of occurrence and the consequences of natural and man-made disasters has attracted a close attention of the scientific community, for example, the International Association of Mathematical Geosciences (IAMG). The organization focuses on the development of geostatistical and geospatial approaches to natural resource characterization and environmental forecast. In this contest, specialized groups and laboratories integrated with GIS have been established abroad.
However, their work is related to the preparation of cartography materials to address environmental management issues with regard to the differentiating of ownership rights to natural resources. In addition, research teams involved into studying a conception of 3D modeling active geological structures development and its direction, as well as the prediction of the development of dangerous seismic geodynamic processes using GIS technologies for solving fundamental and applied tasks and reducing the risks of their occurrence are clearly insufficient.

This is largely due to the complexity of integrating the computational geodynamic (tectonophysical) models to GIS and obtaining representative, verified data without detailed 3D analysis of geological and tectonic structure as well as geophysical fields of studied territories.

\section{IMPROVEMENT OF METHODS FOR FORECASTING AND PREVENTING TECHNOGENIC ACCIDENTS}

As it has been noted, the SE Transbaikal region has historically been a major supplier of strategic metals for the country's economy (gold, uranium, copper, rare metals, etc.) [Bortnikov and Petrov, 2020]. Most of the ore deposits are associated with the Late Mesozoic tectonomagmatic activation, which was the most productive in the manifestation of tectonotermal events and ore-genetic processes that determine metallogenic territory's image [Andreeva et al., 2020; Petrov et al., 2017a]. However, the territory is not provided with a system of continuous observations after lithosphere deformation, although further prospects of MRB development are linked here with work on deep horizons of longterm exploitable deposits under complicated geological and mining conditions. In addition to these problems we have identified two geological and geophysical factors:

1. Mismatch of structural plans of deformations for pre-Mesozoic time and Mesozoic activation events;

2. Areas confinedness of modern earthquakes' manifestation to ore fields and deposits controlled by activation fault structures of northwest - southeast orientation whereas Geological structures formed in pre-Mesozoic geological time have a regional northeast-southwest direction.

This, in particular, has led to the same spatial orientation of Seismic Source Zones (SSZ) in the SE Transbaikal region (Figure 1), reflected in a set of maps for general seismic zoning of the territory of the Russian Federation OSR-97 [OSR-97, 1999].

However, geostructural and tectonophysical data indicate that during the Late Triassic-Middle Juras- 


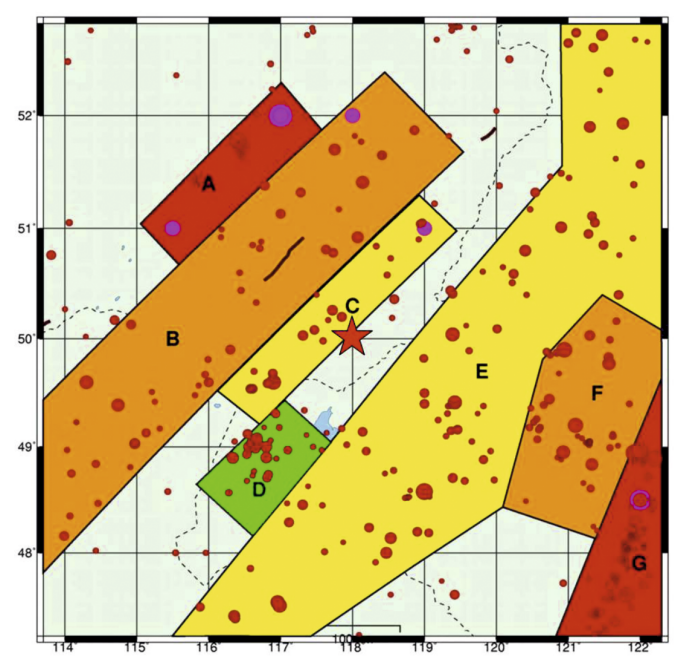

A

\begin{tabular}{|c|c|c|c|}
\hline No & SSZ Zone & Mmax & $\begin{array}{c}\text { Depth, } \\
\text { km }\end{array}$ \\
\hline 1 & A & 6.0 & 20 \\
\hline 2 & G & 6.0 & 20 \\
\hline 3 & B & 5.5 & 15 \\
\hline 4 & F & 5.5 & 15 \\
\hline 5 & C & 5.0 & 12 \\
\hline 6 & E & 5.0 & 12 \\
\hline 7 & D & 4.5 & 10 \\
\hline & Background & $\mathbf{3 . 5}$ & $\mathbf{6}$ \\
\hline
\end{tabular}

B

Figure 1: A - location of Seismic Source Zones (SSZ) in SE Transbaikal and adjacent areas of Mongolia and China. Red Star - "PIMCU" territory location. B - Parameters of the SSZ, including maximum magnitude $\left(M_{\max }\right)$ and hypocenter location depth $(\mathrm{km})$.

sic time, the region experienced a tectonic stress inversion caused by restructuring of global tectonic field [Delvaux et al., 1995, 1997]. As a result of Mesozoic tectonomagmatic (tectonothermal) activation events manifestation, the northwest-southeast extension fault network was formed. They have been ore-hosting for a number of ore fields (Baley, Novoshyrokinskyi, Kalga, Streltsovskoye, etc) and strategic metal deposits in Transbaikal. It is significant that modern seismic processes were the most intensely demonstrated within large ore fields and in close proximity to them (Figure 2).

A specific task addressed within the problem of studying the natural external causes of possible technogenic accidents in the SE Transbaikal region is the research integration on three interrelated areas: geoinformation and analytical, geo-structural tectonic and computational geodeformation.

The Geoinformation Analysis (GIA) block fulfils the task of creating a unified geo-information platform of work, including the systematization of milestones of accessible geological, geophysical, geodynamic, tectonic, metallogenic, hydrographic and other data related to SE Transbaikal. This is achieved by establishing a distributed base of geodata in the form of attribute tables and thematic layers of cartographic products (topographic, geological, tectonic, hydrogeological, metallogenic and other maps on a scale from $1: 500,000$ to $1: 200,000)$, linked to a unified coordinate system.

Geostructural tectonic research (STR) block solves the problem of creating a framework of fault tectonics of the SE Transbaikal territory, identification of rock massifs geological development features, identification of main stages of tectogenesis, zoning the territory according to degree of geodynamic activity. In addition, the direction of seismogeodynamic processes development is being evaluated, and the basic parameters of the rock massifs SS state are being determined for strategic deposits of uranium, gold, polymetals, copper, rare metals, etc. where destructive natural and man-made processes manifest themselves.

Computational geodeformation research (CGR) block solves the problem of building geostructure models, properties and rheological links of the geological environment, determination of boundary conditions for numerical tectonophysical modeling of hazardous seismogeodynamic processes, conducting of $2 \mathrm{D}$ and $3 \mathrm{D}$ modeling of modern SS state of rock massifs with active fault-fracture separation, integration of computed geodynamic models into the SE Transbaikal GIS consolidated project.

Such a formulation of the question of study and evaluation of the development patterns of modern geodynamic processes and seismotectonic events that manifest themselves in the territories of enhanced technogenic and environmental hazard in the SE Transbaikal region is unprecedented and has no equivalent in scale.

The task has all characteristics of originality on two main circumstances:

- For the first time the external natural causes of possible technogenic accidents in geodynamic environment and calm modern intraplate seismicity are determined on a geoinformation basis;

- For the first time 3D models of the modern geodynamic development processes and dangerous seismotectonic events are integrated into the territorially oriented GIS.

Substantiation of the attainability of performance targets to identify trigger mechanisms, and the de- 


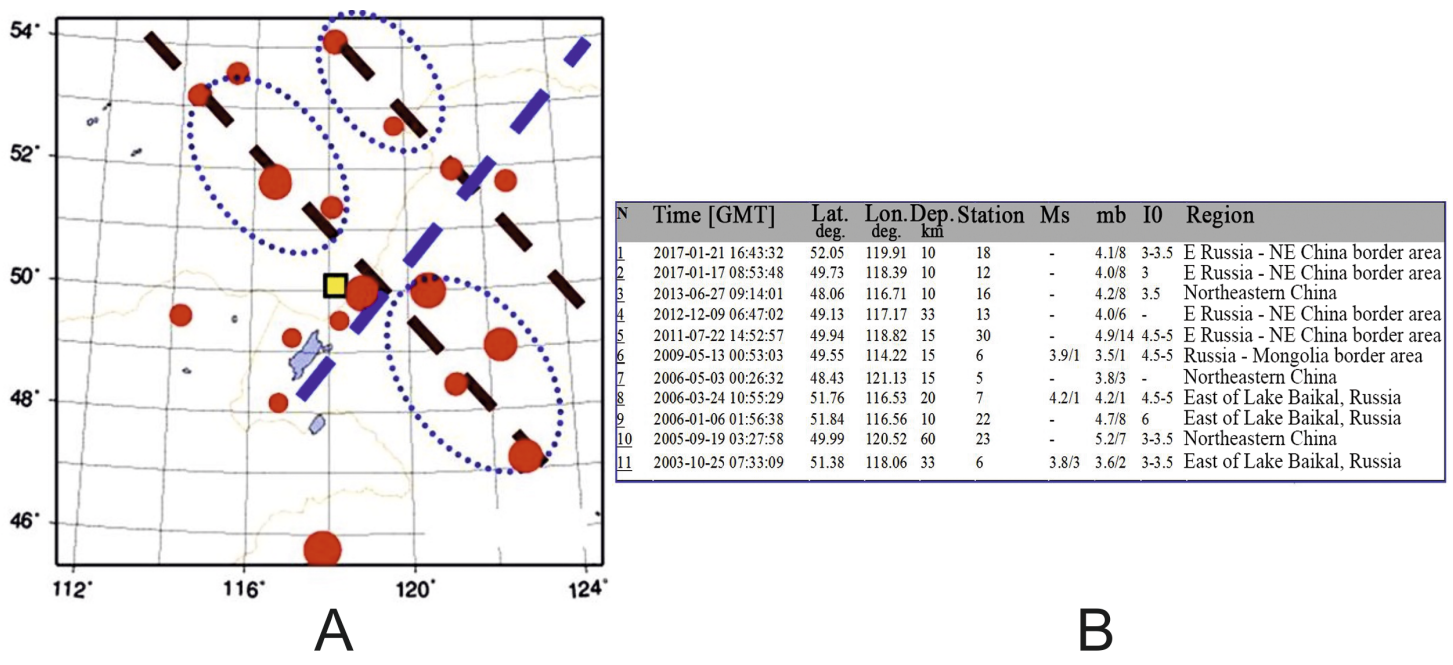

Figure 2: A - association the fault structures of the north-west - south-east extension with earthquake epicenters recorded in the area (50.00 latitude, 118.00 longitude, $300 \mathrm{~km}$ radius) for the period of 2003-2017 (according to Federal Research Center “Geophysical Survey of Russian Academy of Sciences”). Blue dotted line - is basic earthquake clusters, yellow square - "PIMCU" territory location. $\mathrm{B}$ - an example of recording earthquake parameters from database.

velopment of seismotectonic activity areas is as follows. It is known that the main seismic activity is concentrated along global fault (shear) zones, separating stable lithospheric plates. The SanAndreas Fault between the Pacific and North American plates line along the coast of the state of California for about $1200 \mathrm{~km}$, as well as the North Anatolian Fault between the Eurasian and Anatolian plates are an illustrative example of it. Here, according to geological and cosmogeodesic data, the speed of modern displacements is $13-20 \mathrm{~mm} /$ year, but the total value of the relative displacement of plates reaches $30 \mathrm{~mm}$ /year due to deformations in the near-fault zone with a width of more than 100 $\mathrm{km}$. Such seismically active structures have long been studied by national and international groups of researchers. For example, in the San Andreas Fault zone, there is an underground observatory at the Parkfield site (San Andreas Fault Observatory at Depth, SAFOD [SAFOD, 2021]), where under the aegis of the United States Geological Survey (USGS) geological and geophysical researches are conducted and a system of monitoring seismic activity, deformation and fluid flow of the fault was created [Roeloffs, 2000]. The system, which has been operational since 2004, is organized in a fan of wells, overdrilled the prospective area of the master fault the San Andreas Fault [Hickman et al., 2004].

However recently, tectonically stable areas within lithospheric plates where intraplate seismicity is developed have attracted more and more attention of specialists. Detailed and comprehensive study of the intraplate seismic phenomenon has begun relatively lately [Stein and Mazzotti, 2007]. The New Madrid seismic zone in the south-east of the United States, where historic earthquakes have been recorded, resulting in repeated destructions and human casualities is an example. Now its study is due to the fact that the Mississippi River Valley which stretches for hundreds of kilometers along the seismic zone is densely inhabited. Specialists state that unlike interblock lithospheric boundaries the mechanisms of origin and the development of seismic processes within tectonically passive intraplate areas are largely unstudied that makes it difficult to assess the seismic risk to the population and infrastructure in such territories. This fully applies to the SE Transbaikal region.

\section{Alleged approach}

We propose to approach the issue solution of intraplate seismic mechanisms from geological, structural and geodynamic positions. A preliminary analysis of the geological and geophysical resources available for SE Transbaikal shows that areas of modern seismic activity concentrated at the intersection nodes of differently oriented regional fault zones [Gorshkov and Soloviev, 2021] where intensive fluid-magmatic processes have manifested themselves since Mesozoic (Streltsovskoye uranium field, Baley gold vein field, Kalga polymetallic field, Novoshirokinskoye gold-polymetallic field, etc.) (Figure 3)

It seems that a combination in space areas of Meso-Cenozoic ore genesis regions with modern seismic activity has deep genetic roots. The only way to reveal these relationships is possible only with the involvement all available geological, geophysical and metallogenic data.

The assigned tasks' achievability deals with the integration of $3 \mathrm{D}$ computational models of mod- 


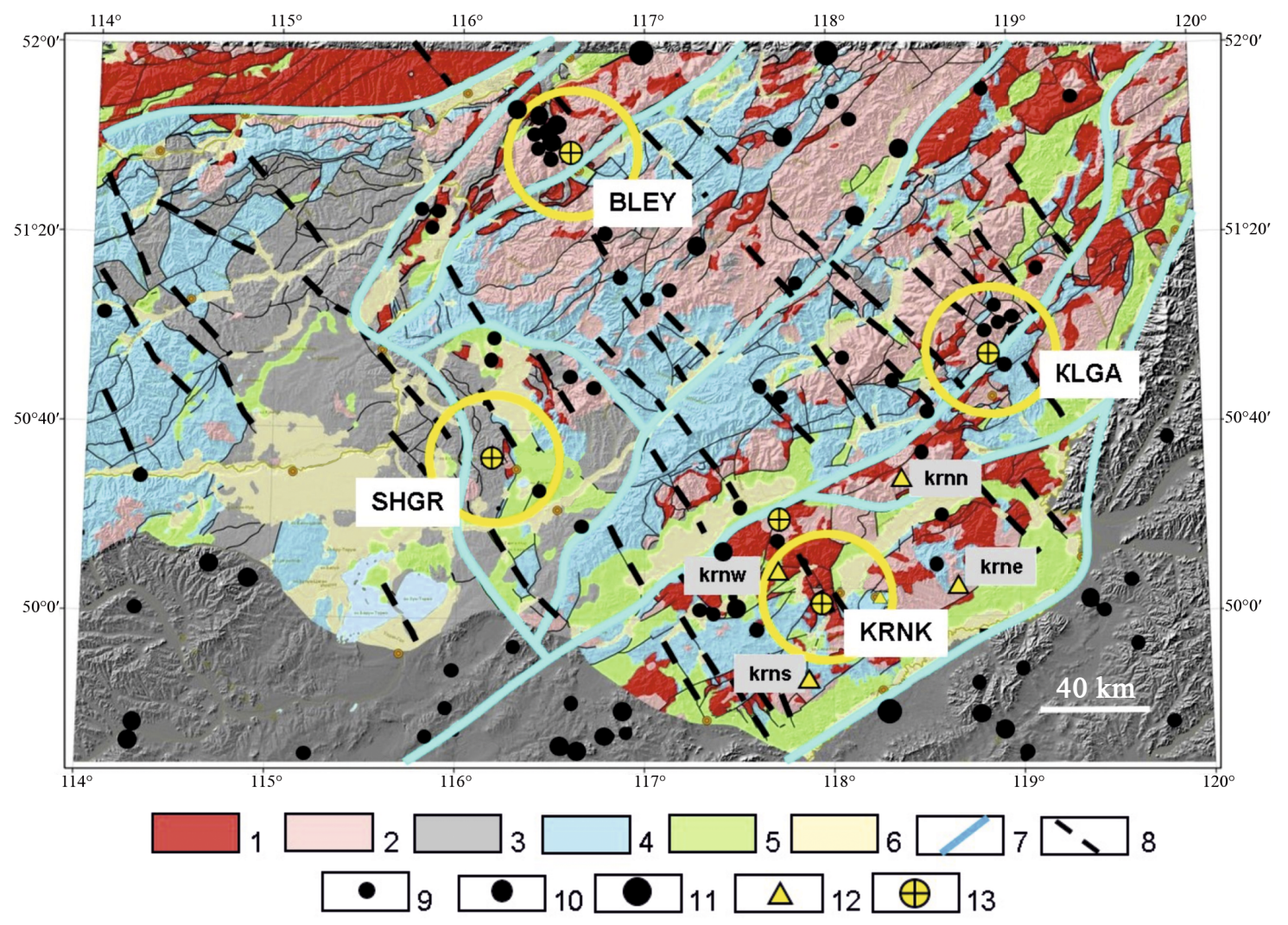

Figure 3: The SE Transbaikal GIS Project based on geological, tectonic and geophysical materials in scale from 1:1,000,000 to 1:100,000. 1 - AR-PZ1 granitogneiss and complex magmatic rocks; 2 - MZ-PZ granite (intrusions); 3 - PZ volcanogenic-sedimentary complexes; 4 - MZ volcanogenic-sedimentary complexes; 5 - Cretaceous sedimentary-volcanogenic complexes; 6 - N-Q sediments; 7 - major regional faults; 8 - secondary and local regional fracture zones; 9-11 - earthquake epicenters with various magnitude $\left(M_{\text {cal }}\right)$ : 0-2.9 (9), 3-3.38 (10), 3.9-6.0 (11); 12 - geodesy GPS stations; 13 - main sites of seismic geodynamic observations. Ore fields: BLEY - Baleyskoye, SHGR - Sherlovogorskoye, KLGA - Kalginskoye, KRNK - Streltsovskoye.

ern geodynamic processes and dangerous seismotectonic phenomena into GIS of the SE Transbaikal region development is due to the logic of the approach we develop that includes the following activities. First, a regionally centralized and thematically distributed base of geological and geophysical data in the form of attribute tables and thematic layers of cartographic materials with raster and vector images (topographic, geological, tectonic, geophysical, hydrogeological, metallogenic and other maps on a scale from 1:5,000,000 to 1:200,000), which are linked to a single coordinate system, is created.

Further, on this basis 3D models of geological and tectonic structure and region's geodynamic is formed; and then 3D fault network models and rock masses of different formational affiliation and properties are being established (Figure 4)

On the basis of 3D geotectonic structural models and with the help of finite element method specialized programs the tectonophysical modeling of modern stress and strain fields was carried out. Methodology and results of tectonophysical model- ing, results of which are integrated into 3D GIS built on ArcGIS 10 platform with a model ArcGIS 3D Analyst, are described in [Petrov et al., 2017b] and there is no need to repeat them. In this context it should be noted, that estimated 2D and 3D models of SS state of rock massifs are verified at two scale levels: regional on the example of the Klichkinskaya seismic dislocation which is active from the middle of the Pliocene up to present days (Figure 5) and local scale on the example of the Antei uranium deposit in Streltsovskoye ore field [Petrov et al., 2015].

Good comparability of estimated 3D tectonophysical modeling (finite element method) of SS state of rock massifs and data on day surface displacement towards satellite gathered from interferometric treatment (30 images were used) of multi-pass radar satellite imagery by spaces craft Sentinel 1B during the period April-October 2020 Figure 6 should also be noted.

Interferometric processing of radar satellite data was carried out by using the method of stable reflectors devised by Hooper et al. [2004] and imple- 


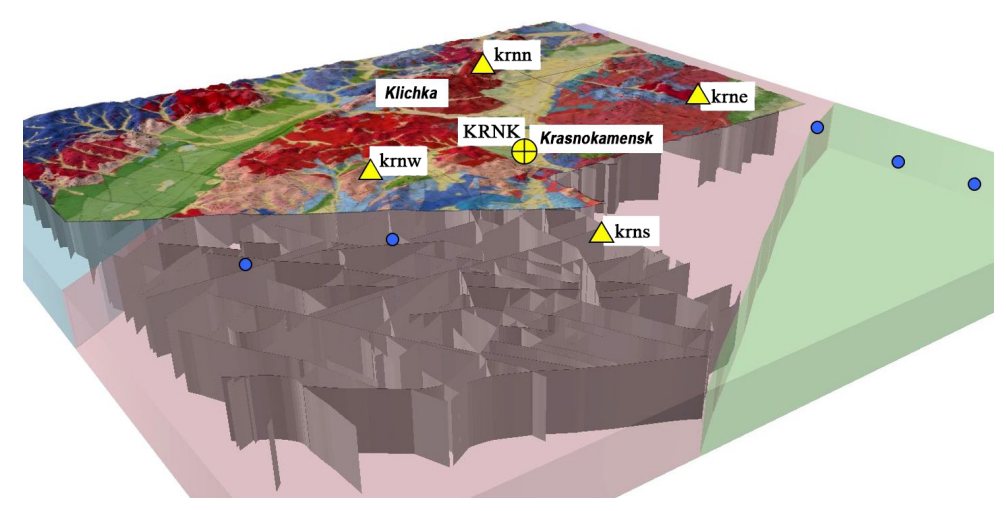

Figure 4: 3D model example of geotectonic structure of SE Transbaikal in the vicinity of Krasnokamensk town. GPS stations to observe dynamics of the Earth's surface displacement, organized by the specialists from group of V. A. Sankov of IZK SB RAS [Petrov et al., 2017b]: KRNK - is basic station on the "PIMCU” territory; krmv, krne, krns - temporary stations. Blue dots show earthquake's hypocenters after 2000.

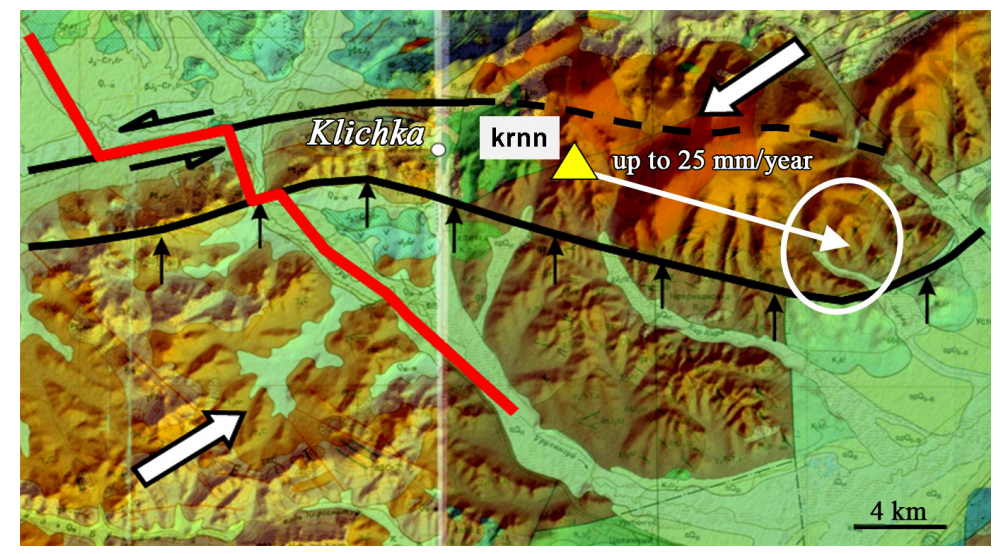

Figure 5: Klichkinskiy Ridge: combination of digital relief model and geological map (scale 1:200,000). The path of the fault (Klichkinskaya latitudinal seismic dislocation) active in the late Cenozoic (from middle Pliocene to the present days that is about $5 \mathrm{Ma}$ ) is shown. The figure also shows sinistral displacement along its master fault plane (black arrows), position of the monitoring station of the earth's surface movement (yellow triangle) provided by GPS geodesy method carried out by the group of specialists headed by V. A. Sankov (IZK SB RAS, Irkutsk) and the direction of dynamic compressive forces (white arrows).

mented in the software package StaMPS (Stanford Method for Persistent Scatterers). The main feature of this method distinguished it from classical, suggested by Ferretti et al. [2000], is that it frees the researcher from the need to construct hypotheses about how the rate of displacement changes over time; that is the analysis of the distribution of stable reflectors by spatial and not temporal factor is carried out. This approach is important for natural objects analysis which character of rate displacement changes over time is unknown, but must be determined according satellite interferometry data. This method can also be used to select stable reflectors at natural sites where the intensity of reflection is significantly lower but technogenic facilities are well distinguished [Dmitriev, 2013].

Comparison of these materials shows that the most intensive downward movements are cur- rently taking place in the north-west part of Streltsovskoye ore field where geological structures of Streltsovskaya caldera are submerged under quaternary sediments of the Sukhoy Urulyunguy depression. Along with this the central and the southeast parts of caldera where the uranium deposits are being localized and new mines facilities are under construction, predominantly experience relative uplift that is accompanied by changes in parameters of SS state in the section of ore-bearing rock massifs.

In this regard the establishment and implementation of regional SS state model for geological structures in combination with a detailed analysis of materials on remote sensing of the Earth makes it possible to carry out measures to ensure the safety of mining operations in complex geomechanical and rockburst hazardous conditions at operating and under construction mines within the "PIMCU" ter- 


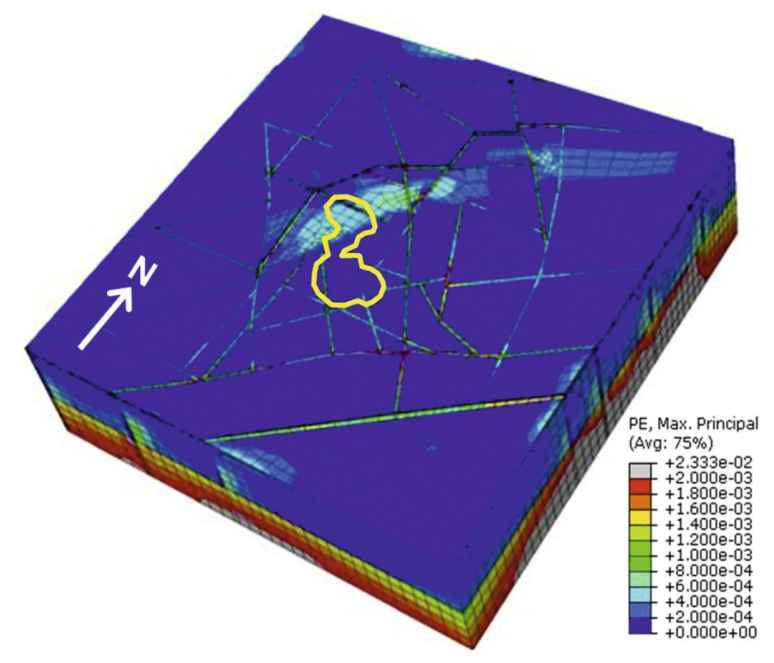

A

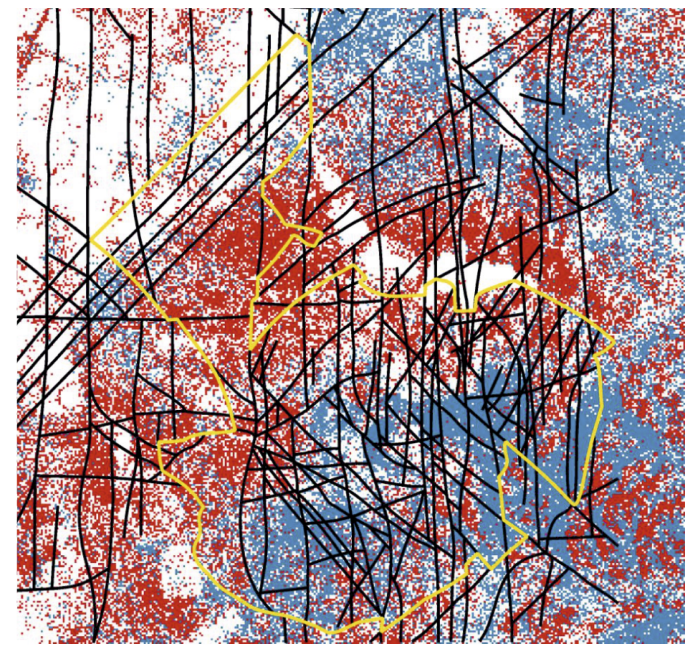

B

Figure 6: A - 3D tectonophysical model of calculated intensity of the maximum principal elasto-plastic deformations (PE max) on the surface (from +1 to $0 \mathrm{~km}$ a.s.l.) provided that loading is determined by own weight of rocks. B - Map of vertical displacements reflecting natural and man-made objects (red lowering, blue - raising) of the day surface on the "PIMCU" territory received on the basis of interferometric processing of a spaceship D33 Sentinel-1B for the period of April-October 2020. Yellow line - is a contour of Streltsovskaya uranium-bearing caldera.

ritory on a unified methodological geoinformation basis, as well as use of the results of tectonophysical modeling to assess the flanks and deep horizons of the ore field in order to identify new uranium ore accumulations.

\section{Conclusion}

The basic research results at present time are:

- A rational set of technologies of the global Internet network (Web), network of analytical geoinformation systems (GIS) and distributed computing networks (GRID) was selected and used to create an information and analytical collecting complex for processing and analyzing of a large array of non-homogeneous geological and geophysical data to determinate the development patterns of modern geodynamic processes and seismotectonic phenomena that create preconditions for technogenic accidents related in areas with high-risk facilities;

- Optimal information flows strategies and methods that realize the advantages of highperformance processing technologies, concentration and distribution of digital data in combination with software training tools of scientific and methodological materials of automated spatial analysis of documentary information arrays of integrated databank in the field of geosciences and rational use of natural resources have been determined;
- Experimental modes of operation using the technology of automated creation in GIS of distributed problem-oriented information field with the involvement of heterogeneous monitoring data were conducted on the example of the SE Transbaikal region;

- 3D geotectonic structural model of the territory and 3D tectonophysical model of SS state of rock massifs demonstrating the results achieved in the field of geodynamic activity evaluation have been developed and constructed.

Integration of estimated models into GIS project of the SE Transbaikal region allows verifying the model results directly in rock outcrops at points with specific geographical coordinates. It gives the opportunity to assess the dynamic of the development of dangerous natural and technogenic phenomena for specific geological structures, their individual segments or areas. This is the first time that such an approach to environmental forecasting has been implemented.

\section{Acknowledgements}

The work was carried out within the framework of the state task of IGEM RAS on the topic "Development of geoinformation models of mineral systems of strategic metal deposits (on the example of southeastern Transbaikal region)". 


\section{REFERENCES}

Adushkin, V. V., and S. B. Turuntaev, Technogenic processes in the Earth's crust, 252 pp., Moscow: INAK, (in Russian), 2005.

Ahern, D. F., and N. P. Laverov (Eds.), Internationalization of the Nuclear Fuel Cycle, National Academies Press, Washington, DC, doi:10.17226/12477, 2009.

Andreeva, O. V., V. A. Petrov, and V. V. Poluektov, Mesozoic Acid Magmatites of Southeastern Transbaikalia: Petrogeochemistry and Relationship with Metasomatism and Ore Formation, Geology of Ore Deposits, 62(1), 69-96, doi:10.1134/s1075701520010018, 2020.

BGI, International Gravimetric Bureau, ht tp : / / www . bgi . obs-mip.fr/, accessed: 2021-06-07, 2021.

Bortnikov, N. S. (Ed.), Fundamental basis of formation of a resource base of strategic raw materials ( $\mathrm{Au}, \mathrm{Ag}, \mathrm{Pt}, \mathrm{Cu}$, rare elements and metals), 340 pp., Geos, Moscow., (in Russian), 2012.

Bortnikov, N. S., and V. A. Petrov (Eds.), Strategic and hightech metal deposits of the Russian Federation: patterns of placement, conditions of formation, innovative technologies for forecasting and development (Program's results $N$ 1. 48 Presidium RAS), 317 pp., (in Russian), 2020.

Bortnikov, N. S., V. A. Petrov, A. V. Veselovskiy, et al., Geoinformation system (gis) of transbaikal sector of mongolian-okhotsk mobile belt, Ores and Metals, (3), 18-27, (in Russian), 2012.

Bugaev, E. V., I. V. Kaliberda, I. M. Lavrov, and L. M. Fihieva, Problems of regulatory support for the safe location of nuclear facilities, Nuclear and Radiation Safety, 2, 114-121, 2005.

Catalogue, Catalogue of rock bursts at ore and nonmetallic deposits (Severouralsk, Tashtagol, October, Norilsk, Yukspor, Kukisvumchorskoye (PO "Apatite"), Kochkarskoye and other deposits, (in Russian), 1989.

Delvaux, D., R. Moeys, G. Stapel, A. Melnikov, and V. Ermikov, Palaeostress reconstructions and geodynamics of the Baikal region, Central Asia, Part 2. Palaeozoic and Mesozoic pre-rift evolution, Tectonophysics, 252(14), 61-101, doi:10.1016/0040-1951(95)00090-9, 1995.

Delvaux, D., R. Moeys, G. Stapel, C. Petit, K. Levi, A. Miroshnichenko, V. Ruzhich, and V. San'kov, Paleostress reconstructions and geodynamics of the Baikal region, Central Asia, Part 2. Cenozoic rifting, Tectonophysics, 282(1), 1-38, doi:https://doi.org/10.1016/S0040-1951(97)00210-2, structural Controls on Sedimentary Basin Formation, 1997.

Dmitriev, P. N., New methods of processing and interpretation of radar satellite interferometry data: dissertation for the degree of candidate of physical and mathematical sciences, 124 pp., IFZ RAS, Moscow, (in Russian), 2013.

Ferretti, A., C. Prati, and F. Rocca, Nonlinear subsidence rate estimation using permanent scatterers in differential sar interferometry, IEEE Transactions on Geoscience and Remote Sensing, 38(5), 2202-2212, doi:10.1109/36.868878, 2000.

Geotechnologien, Geoscientific Research and Development Programme, http: //www. geotechnologien.de/, accessed: 2021-06-10, 2021.

Gliko, A. O. (Ed.), Extremal natural events and disasters. Vol. 2: Uranium geology, geoecology, glaciology, 431 pp., IFZ RAS, Moscow, (in Russian), 2011.

Gorshkov, A. I., and A. A. Soloviev, Recognition of earthquake-prone areas in the altai-sayan-baikal region based on the morphostructural zoning, Russian Journal of Earth Sciences, 21, ES1005, doi:10.2205/2020ES000751, 2021.

Heidbach, O., M. Rajabi, K. Reiter, and M. Ziegler, World stress map 2016, GFZ Data Services, 2, doi:10.5880/WSM.2016.002, 2016.

Hickman, S., M. Zoback, and W. Ellsworth, Introduction to special section: Preparing for the san andreas fault observatory at depth, Geophysical Research Letters, 31(12), doi:10.1029/2004GL020688, 2004.

Hooper, A., H. Zebker, P. Segall, and B. Kampes, A new method for measuring deformation on volcanoes and other natural terrains using insar persistent scatterers, Geophysical Research Letters, 31(23), L23,611, doi:10.1029/2004GL021737, 2004.

Kreuzer, O., V. Markwitz, A. Porwal, and T. McCuaig, A continent-wide study of australia's uranium potential: Part i: Gis-assisted manual prospectivity analysis, Ore Geology Reviews, 38(4), 334-366, doi:https://doi.org/10.1016/j.oregeorev.2010.08.003, 2010.

Kurlenia, M. V., V. M. Seryakov, and A. A. Yeremenko, Technogenic geomechanical stress fields, 264 pp., Novosibirsk: Nauka, (in Russian), 2005.

Laverov, N., and D. Rundkvist (Eds.), Large and super large deposits of ore minerals (Three Volumes), IGEM RAS, Moscow, (in Russian), 2020.

Luhnev, A. V., V. A. Sankov, A. I. Miroshnichenko, et al., Rotation of the earth's surface deformation in the baikal-mongolian region according to gps measurement, Geology and Geophysics, 51(7), 1006-1017, 2010.

Mallet, J.-L., Space-time mathematical framework for sedimentary geology, Mathematical Geology, 36(1), 132, doi:10.1023/b:matg.0000016228.75495.7c, 2004.

Mallet, J.-L., and A.-L. Tertois, 3d restoration of sedimentary terrains: The geochron approach, arXiv preprint arXiv:2105.06137, 2021.

OSR-97, Set of maps for general seismic zoning of the territory of the Russian Federation (OSR-97), (in Russian), 1999.

Petrov, V. A., A. V. Vesdovskiy, and D. A. Kuzmina, Modeling and monitoring of geodynamic situation with the help of geoinformation system, Scientific Review, (8), 133-138, (in Russian), 2014. 
Petrov, V. A., Yu. L. Rebetsky, V. V. Poluektov, and A. A. Burmistrov, Tectonophysics of Hydrothermal Ore Formation: an Example of the Antei Mo-U Deposit, Transbaikalia, Geology of Ore Deposits, 57(4), 292-312, doi:10.1134/s1075701515040030, 2015.

Petrov, V. A., O. V. Andreeva, V. V. Poluektov, and D. V. Kovalenko, Tectono-Magmatic Cycles and Geodynamic Settings of Ore-Bearing System Formation in the Southern Cis-Argun Region, Geology of Ore Deposits, 59(6), 431-452, doi:10.1134/s1075701517060034, 2017a.

Petrov, V. A., A. B. Leksin, V. V. Pogorelov, Yu. L. Rebetsky, V. A. San'kov, S. V. Ashurkov, and I. Yu. Rasskazov, Geodynamic simulation of ore-bearing geological structural units by the example of the Strel'tsovka uranium ore field, Geology of Ore Deposits, 59(3), 183-208, doi:10.1134/s1075701517030047, 2017b.

Roeloffs, E., The Parkfield, California earthquake experiment: An update in 2000, Current Science, 79(9), 12261236, 2000.

Rostekhnadzor, Federal norms and rules in the field of atomic energy use accounting for external influences of natural and man-made origin on nuclear facilities (OIAE) NP-064-05, (in Russian), 2005.
SAFOD, San Andreas Fault Observatory at Depth, https : //safod.icdp-online.org/, accessed: 2021-06-15, 2021.

Sankov, V. A., K. G. Levi, A. V. Luhnev, and A. I. Miroshnichenko, Modern movements of lithospheric blocks in central asia according to gps-geodesy data, Actual issues of Central Asia modern geodynamic, pp. 165-179, (in Russian), 2005.

Sobolev, G. A., Concept of predictability of earthquakes based on the dynamics of seismicity under trigger action, pp. 1543, IFZ RAS, Moscow, (in Russian), 2010.

Stein, S., and S. Mazzotti, Continental Intraplate Earthquakes: Science, Hazard, and Policy Issues, Geological Society of America, doi:10.1130/SPE425, 2007.

Ulomov, V. I., and M. I. Bogdanov (Eds.), General seismic zoning of the territory of the Russian Federation. An explanatory note to maps' set OSR-2016 and a list of settlements located in seismically active zones, 73 pp., IFZ RAS, Moscow, (in Russian), 2017.

$\begin{array}{cccc}\text { WSM, World Stress } & \text { Map, http: // www . } \\ \text { world-stress-map.org/, accessed: } & \text { 2021-06-20, }\end{array}$ 2021. 